JKM (Jurnal Kebidanan Malahayati),Vol 7,No.3.Juli 2021,

ISSN (Print) 2476-8944 ISSN (Online) 2579-762X, Hal 453-458

\title{
HUBUNGAN RIWAYAT KEJANG DEMAM DENGAN KEJADIAN EPILEPSI PADA ANAK $\leq 5$ TAHUN DI RSUD Dr. H. ABDUL MOELOEK PROVINSI LAMPUNG TAHUN 2018-2019
}

\author{
Novi Komala Sari ${ }^{*}$, Nina Herlina ${ }^{2}$, Aswan Jhonet ${ }^{2}$ \\ 1,2,3Kedokteran, Fakultas Kedokteran, Universitas Malahayati, Lampung \\ *Korespondensi email novikomala9h@gmail.com
}

\begin{abstract}
THE RELATIONSHIP BETWEEN THE HISTORY OF FEBRILE SEIZURE AND THE OCCURENCE OF EPILEPSY AMONG CHILDREN $\leq 5$ YEARS OLD IN DR. H. ABDUL MOELOEK LAMPUNG PROVINCE 2018-2019
\end{abstract}

Background : Epilepsy is a neurological disorder which often found in the world and has the highest incidence in children. The most common risk factor of epilepsy is febrile seizure. Febrile seizure refer to a seizure following by high-fever $\left(>38^{\circ} \mathrm{C}\right)$ that often found in the age between 6 month -5 years old. Objective : This study aim to acknowledge the relation between the febrile sizure history and the incidence of epilepsy found in the children of $\leq 5$ years old in RSUD Dr. H. Abdul Moeloek Lampung Province 2018-2019.

Methods: This study used an analytic research design with cross sectional approach. The population being used are all pediatric patients in the age of $\leq 5$ years which diagnosed with epilepsy in RSUD Dr. H. Abdul Moeloek Lampung Province. Further, the sample being used in this research are 42 people which obtained from total sampling technique. While the statistic test being used is Chi square test.

Results :Tthis study is show that 31 children (73.8\%) had a febrile seizure history, and 11 children (26.2\%) had not a febrile seizure history. Further, this study found that 8 children (19.0\%) had a partial awakening epilepsy, and 34 children (81.0\%) had a general awakening epilepsy. The result of chi square examination which is ( $p$ value 0.032) showed that there is a relation between the febrile seizure history and the incidence of epilepsy found in children at age of $\leq 5$ yearch in RSUD Dr. H. Abdul Moeloek Provinsi Lampung in the year of 2018-2019.

Conclusion : There is a relation between febrile seizure history and the incidence of epilepsy found in child.

Suggestion : It is recommended to be able to pay attention, add insight about febrile seizures and epilepsy, so that mothers don't panic and know how to overcome them.

Keywords : Febrile Seizure, Epilepsy, Child

\section{ABSTRAK}

Latar Belakang : Epilepsi merupakan kelainan neurologis yang sering ditemui di dunia dan insidensinya terbanyak pada masa anak-anak. Faktor risiko epilepsi yang tersering adalah kejang demam. Kejang demam mengacu pada kejang yang berhubungan dengan demam tingkat tinggi $\left(>38^{\circ} \mathrm{C}\right)$ yang sering terjadi pada usia 6 bulan -5 tahun.

Tujuan Penelitian : Penelitian ini bertujuan untuk mengetahui hubungan riwayat kejang demam dengan kejadian epilepsi pada anak $\leq 5$ tahun di RSUD Dr. H. Abdul Moeloek Provinsi Lampung 2018-2019. Metode Penelitian : Penelitian ini menggunakan desain penelitian analitik dengan pendekatan cross sectional. Populasi yang digunakan adalah semua pasien anak usia $\leq 5$ tahun yang didiagnosis epilepsi di RSUD Dr. H. Abdul Moeloek Provinsi Lampung. Sampel dalam penelitian ini berjumlah 42 orang yang diambil dengan teknik total sampling. Uji statistik yang digunakan adalah uji Chi Square.

Hasil Penelitian : Hasil penelitian ini menunjukkan sebanyak 31 anak (73.8\%) memiliki riwayat kejang demam, serta 11 anak (26.2\%) tidak memiliki riwayat kejang demam. Dan didapatkan sebanyak 8 anak (19.0\%) memiliki epilepsi bangkitan parsial, serta 34 anak (81.0\%) memiliki epilepsi bangkitan umum. Hasil uji Chi Square yaitu ( $p$ value 0.032 ) terdapat hubungan anatara riwayat kejang demam dengan kejadian epilepsi pada anak $\leq 5$ tahun di RSUD Dr. H. Abdul Moeloek Provinsi Lampung Tahun 2018-2019.

Kesimpulan : Terdapat hubungan antara riwayat kejang demam dengan kejadian epilepsi pada anak.

Saran : Disarankan untuk dapat memperhatikan, menambah wawasan tentang kejang demam dan epilepsi, sehingga ibu tidak panik dan mengetahui cara penanggulangannya.

Kata Kunci : Kejang Demam, Epilepsi, Anak. 


\section{PENDAHULUAN}

Kejang demam mengacu pada kejang yang berhubungan dengan demam tingkat tinggi $\left(>38^{\circ} \mathrm{C}\right)$ yang terjadi pada pasien yang sehat secara neurologis. Insidens yang sering terjadi adalah pada anak-anak berusia antara 6 bulan dan 5 tahun, yang tidak disebabkan oleh infeksi intrakranial dan tanpa riwayat kejang unprovokasi sebelumnya (Paul dan Bagga, 2019). Antara 2\% dan 5\% bayi dan anak-anak yang sehat secara neurologis mengalami setidaknya satu kejang demam, biasanya kejang demam sederhana. (Kliegman dan Geme, 2019).

Kejang demam di klasifikasikan menjadi dua yaitu, yang pertama adalah kejang demam sederhana yang bersifat umum saat onset, berlangsung $<15$ menit, dan hanya terjadi sekali dalam periode 24 jam pada anak yang normal secara neurologis dan perkembangan. Yang kedua adalah kejang demam kompleks, berlangsung $>15$ menit, berulang dalam waktu 24 jam, atau anak memiliki tantangan neurologis yang sudah ada sebelumnya. (Marcdante dan Kliegman, 2018).

Di berbagai negara angka kejadian kejang demam sangat bervariasi. Di negara maju seperti Amerika Serikat dan Eropa Barat tercatat 2\% sampai $5 \%$ per tahunnya (Hasibuan dan Dimyati, 2020). Di Asia tercatat dua kali lebih banyak pravelensi kejadian kejang demam, di India 5-10\% dan 6-9\% di Jepang. Insiden tertinggi di Guam yaitu 14\%. (Leung et al., 2018).

Kejang demam di Indonesia pada tahun $200517,4 \%$, dan meningkat pada tahun 2007 yaitu sebesar 22,2\% berdasarkan hasil Survey Demografi Kesehatan Indonesia (SDKI) (Indrayati dan haryanti, 2019). Di lampung angka pasti kejadian kejang demam belum diketahui, Dalam hasil penelitian oleh Amatiria et al., pada tahun 2016 di RSUAM Provinsi Lampung terdapat 37 anak, RSD Demang Sepulau Raya Lampung Tengah 7 anak, dan di RSD Mayjend H.M Ryacudu Kotabumi Lampung Utura sebanyak 61 anak yang mengalami kejadian kejang demam. (Nurhayati et al., 2017).

Hampir semua jenis epilepsi dapat didahului dengan kejang demam (Kliegman dan Geme, 2019). Faktor risiko kejang demam terhadap terjadinya epilepsi adalah: terdapat kelainan neurologis atau perkembangan yang jelas sebelum kejang, kejang demam kompleks, riwayat epilepsi pada orang tua atau suadara kandung, kejang demam sederhana yang berulang 4 episode atau lebih dalam satu tahun. Masing-masing faktor risiko meningkatkan kemungkinan kejadian epilepsi 4-6\%, kombinasi dari faktor risiko tersebut akan meningkatkan epilepsi menjadi $10-49 \%$. (Ismael et al., 2016).

Epilepsi didefinisikan sebagai serangan paroksismal berulang tanpa provokasi dengan interval lebih dari 24 jam tanpa penyebab yang jelas. (Mangunatmadja et al., 2016). Epilepsi menurut Perhimpunan Dokter Spesialis Saraf Indonesia (PERDOSSI) didefinisikan kelainan otak yang ditandai dengan kecenderungan untuk menimbulkan bangkitan epileptik yang terus menerus, dengan konsekuensi neurobiologis, kognitif, psikologis dan sosial. Definisi ini membutuhkan sedikitnya satu riwayat bangkitan epilepsi sebelumnya. (Maryam et al., 2018).

Salah satu dari tiga kelainan neurologis tersering ditemui dipraktek pediatri adalah epilepsi (Andrianti et al., 2016). Epilepsi merupakan salah satu beban yang signifikan dari penyakit di dunia, mempengaruhi sekitar 50 juta orang di seluruh dunia. Epilepsi aktif (kejang yang berlanjut atau dengan kebutuhan pengobatan) antara 4 dan 10 per 1000 orang. Secara global diperkirakan 5 juta orang didiagnosis epilepsi tiap tahunnya. Di negara maju epilepsi diperkirakan ada 49 per 100.000 orang dengan diagnosis epilepsi tiap tahunnya. Sedangkan di negara berkembang angka ini bisa mencapai 139 per 100.000. Hal ini dikarenakan tingginya peningkatan faktor resiko seperti neurocysticercosis, insiden kecelakaan lalu lintas jalan yang lebih tinggi, cedera terkait kelahiran, kondisi endemik seperti malaria. (WHO, 2019). Penderita epilepsi di Indonesia terdapat paling sedikit 700.000-1.400.000 kasus dengan pertambahan sekitar $40-50 \%$ terjadi pada anak. (Permana et al., 2020).

Prevalensi Epilepsi tidak memandang pada laki-laki maupun perempuan, umur berapa saja, dan ras apa saja (Noradina, 2017). Insiden seumur hidup kumulatif dari epilepsi adalah 3\%, dan lebih dari separuh gangguan dimulai pada masa kanakkanak. (Kliegman dan Geme, 2019).

Beberapa studi menunjukkan adanya hubungan antara riwayat kejang demam dengan kejadian epilepsi. Salah satu penelitian yang dilakukan di RSU Cut Meutia Aceh Utara tahun 2015 anak yang mempunyai riwayat kejang demam di Badan Layanan Umum Daerah RSU Cut meutia tahun 2015 sebanyak 13,3\%. Sedangkan anak yang mengalami epilepsi sebanyak $18,3 \%$. Kejang demam maupun epilepsi lebih banyak tejadi pada perempuan. Dan anak yang mengalami kejang demam maupun epilepsi terbanyak pada usia 1-5 tahun. Anak yang mengalami epilepsi dan disertai kejang demam sebanyak $50 \%$, Jadi dalam penelitian tersebut terdapat hubungan antara 
riwayat kejadian kejang demam dengan kejadian epilepsi. (Chairunnisa et al., 2018). Pada penelitian faktor - faktor yang terdapat pada kejadian epilepsi anak usia $\leq 5$ tahun di RSUD DR. H. Abdul Moeloek Bandar Lampung tahun 2012-2014 ditemukan bahwa faktor yang paling banyak adalah kejang demam. (Lestari dan Mudapati, 2014).

\section{METODOLOGI PENELITIAN}

Jenis penelitian yang digunakan dalam penelitian ini adalah jenis penelitian analisis kuantitatif. Penelitian ini dilakukan pada bulan Maret di RSUD Dr. H. Abdul Moloek Provinsi Lampung Tahun 2021. Penelitian ini menggunakan desain analitik dengan pendekatan cross sectional dimana cara pengambilan data variabel bebas dan variabel tergantung dilakukan sekali waktu pada saat yang bersamaan. Populasi dalam penelitian ini adalah pasien anak data ruang inap yang didiagnosis epilepsi usia $\leq 5$ tahun di ruang rekam medis RSUD Dr. H. Abdul Moeloek Provinsi Lampung pada tahun 2018-2019. Sampel pada penelitian ini yaitu menggunakan total sampel yaitu seluruh pasien anak usia $\leq 5$ tahun yang didiagnosis epilepsi di ruang rawat inap RSUD Dr. H. Abdul Moeloek Bandar Lampung 2018-2019. sejumlah 42 orang. Uji statistik yang dipakai adalah uji Chi square pada tingkat kepercayaan sebesar $95 \%$ dan tingkat kemaknaan (a) sebesar 0,05 serta menampilkan nilai OR (odds ratio) dari masing-masing variabel agar terlihat peluang beresiko dari masing-masing variabel.

\section{HASIL DAN PEMBAHASAN \\ Karakteristik Responden}

Tabel 1.

Distribusi Frekuensi Usia dan Jenis Kelamin di RSUD Dr. H. Abdul Moeloek Bandar Lampung 2018-2019

\begin{tabular}{lcc}
\hline $\begin{array}{c}\text { Karakteristik } \\
\text { Responden }\end{array}$ & Frekuensi & Presentase \\
\hline Usia & 12 & $28.6 \%$ \\
$<1$ tahun & 8 & $19.0 \%$ \\
1 tahun & 8 & $19.0 \%$ \\
2 tahun & 8 & $19.0 \%$ \\
3 tahun & 2 & $4.8 \%$ \\
4 tahun & 4 & $9.5 \%$ \\
5 tahun & & \\
Jenis Kelamin & 24 & $57.1 \%$ \\
Laki-Laki & 18 & $42.9 \%$ \\
Perempuan & 42 & $100.0 \%$ \\
\hline \multicolumn{1}{c}{ Total } &
\end{tabular}

Berdasarkan Tabel 1 didapatkan hasil bahwa usia responden terbanyak adalah $<1$ tahun yang berjumlah 12 anak (28.6\%). Berdasarkan data jenis kelamin, didapatkan bahwa sebagian besar berjenis kelamin laki-laki yang berjumlah 24 anak (57.1\%).

\section{Analisis Univariat}

Tabel 2.

Distribusi Frekuensi Riwayat Kejang Demam dan Epilepsi di RSUD Dr. H. Abdul Moeloek Bandar Lampung 2018-2019

\begin{tabular}{lcc}
\hline \multicolumn{1}{c}{ Analisis Univariat } & Frekuensi & Presentase \\
\hline Riwayat Kejang Demam & & \\
Kejang Demam & 31 & $73.8 \%$ \\
Tidak Kejang Demam & 11 & $26.2 \%$ \\
Epilepsi & & \\
Bangkitan Parsial & 8 & $19.0 \%$ \\
Bangkitan Umum & 34 & $81.0 \%$ \\
\hline \multicolumn{1}{c}{ Total } & 42 & $100.0 \%$ \\
\hline
\end{tabular}

Berdasarkan Tabel 2 Distribusi Riwayat Kejang Demam di RSUD Dr. H. Abdul Moeloek Provinsi Lampung dari 42 anak, sebagian besar anak memiliki riwayat kejang demam yaitu sebanyak 31 anak (73.8\%) sedangkan yang tidak memiliki riwayat kejang demam sebanyak 11 anak (26.2\%). Distribusi epilepsi berdasarkan jenis bangkitan di RSUD Dr. H. Abdul Moeloek Provinsi Lampung dari 42 anak, sebagian besar anak memiliki epilepsi bangkitan parsial yaitu sebanyak 8 responden $(19.0 \%)$ sedangkan dengan bangkitan umum sebanyak 34 anak (81.0\%).

\section{Analisis Bivariat}

Hubungan Riwayat Kejang Demam pada Anak $\leq$ 5 tahun dengan Epilepsi di RSUD Dr. H. Abdul Moeloek Provinsi Lampung Tahun 2018-2019

Berdasarkan Tabel 3 hubungan riwayat kejang demam dengan kejadian epilepsi, diketahui bahwa dari 42 anak dengan riwayat kejang demam sebanyak 3 anak $(9,7 \%)$ mengalami epilepsi dengan bangkitan parsial, dan 28 anak $(90,3 \%)$ mengalami epilepsi bangkitan umum. Sedangkan riwayat tidak kejang demam sebanyak 5 anak $(45,5 \%)$ mengalami epilepsi bangkitan parsial, dan 6 responden $(54,5 \%)$ mengalami epilepsi bangkitan umum. Hasil uji statistik diperoleh nilai $p$ value sebesar 0.032 antara hubungan riwayat kejang demam dengan kejadian epilepsi. Sehingga dapat disimpulkan bahwa terdapat hubungan yang bermakna antara Hubungan Riwayat Kejang Demam dengan Kejadian Epilepsi pada anak $\leq 5$ tahun di RSUD Dr. H. Abdul Moeloek Provinsi Lampung. Dari penelitian ini didapatkan bahwa riwayat kejang demam dapat meningkatkan resiko 
12,9 kali lebih besar untuk mengalami epilepsi dibandingkan responden yang tidak memiliki riwayat kejang demam.

Tabel 3.

Hubungan Riwayat Kejang Demam pada Anak $\leq 5$ tahun dengan Epilepsi di RSUD Dr. H. Abdul Moeloek Provinsi Lampung Tahun 2018-2019

\begin{tabular}{|c|c|c|c|c|c|c|c|c|}
\hline \multirow{3}{*}{$\begin{array}{l}\text { Riwayat Kejang } \\
\text { Demam }\end{array}$} & \multicolumn{4}{|c|}{ Epilepsi } & \multirow{2}{*}{\multicolumn{2}{|c|}{ Total }} & \multirow{3}{*}{$p$ value } & \multirow{3}{*}{ OR $95 \% \mathrm{Cl}$} \\
\hline & \multicolumn{2}{|c|}{$\begin{array}{c}\text { Bangkitan } \\
\text { Parsial }\end{array}$} & \multicolumn{2}{|c|}{$\begin{array}{l}\text { Bangkitan } \\
\text { Umum }\end{array}$} & & & & \\
\hline & (n) & $\%$ & (n) & $\%$ & (n) & $\%$ & & \\
\hline Kejang Demam & 3 & 9.7 & 28 & 90.3 & 31 & 100.0 & \multirow{2}{*}{0.032} & 0.129 \\
\hline Tidak Kejang Demam & 5 & 45.5 & 6 & 54.5 & 11 & 100.0 & & $(0.024-0.691)$ \\
\hline Total & 8 & 19.0 & 34 & 81.0 & 42 & 100.0 & & \\
\hline
\end{tabular}

\section{PEMBAHASAN}

Hasil uji statistik diperoleh nilai $p$ value sebesar 0.032 antara hubungan riwayat kejang demam dengan kejadian epilepsi. Sehingga dapat disimpulkan bahwa terdapat hubungan yang bermakna antara Hubungan Riwayat Kejang Demam dengan Kejadian Epilepsi pada anak $\leq 5$ tahun di RSUD Dr. H. Abdul Moeloek Provinsi Lampung. Dari penelitian ini didapatkan bahwa riwayat kejang demam dapat meningkatkan resiko 0,129 kali lebih besar untuk mengalami epilepsi dibandingkan responden yang tidak memiliki riwayat kejang demam.

Hampir semua jenis epilepsi dapat didahului dengan kejang demam (Kliegman dan Geme, 2019). Insiden seumur hidup kumulatif dari epilepsi adalah $3 \%$, dan lebih dari separuh gangguan dimulai pada masa kanak-kanak (Kliegman dan Geme, 2019).

Faktor risiko kejang demam terhadap terjadinya epilepsi adalah: terdapat kelainan neurologis atau perkembangan yang jelas sebelum kejang, kejang demam kompleks, riwayat epilepsi pada orang tua atau suadara kandung, kejang demam sederhana yang berulang 4 episode atau lebih dalam satu tahun. Masing-masing faktor risiko meningkatkan kemungkinan kejadian epilepsi 4-6\%, kombinasi dari faktor risiko tersebut akan meningkatkan epilepsi menjadi $10-49 \%$ (Ismael et al., 2016).

Kejang yang terjadi lebih dari 15 menit dapat menyebabkan kerusakan neuron secara menetap, sementara kejang demam yang terjadi lebih dari 30 menit akan menyebabkan kerusakan pada DNA (Deoxyribose Nucleic Acid) dan protein otak sehingga menimbulkan jaringan parut, hal ini mengakibatkan terganggunya mekanisme homeostatis otak dengan menurunnya proses inhibisi atau penghambat listrik (neutransmitter GABA) dan meningkatkan proses eksitasi atau cetusan listrik (neurotransmitter glutamat).
Mekanisme homeostasis pada otak belum matang dan masih lemah, akan berubah sejalan dengan perkembangan otak dan pertambahan usia, meningkatkan eksitabilitas neuron. Apabila anak mengalami stimulasi berupa demam pada otak eksitabilitas sehingga akan mudah terjadi bengkitan kejang. Jika mekanisme yang tidak seimbang ini terjadi secara berkepanjangan, maka dapat mengakibatkan sklerosis pada jaringan otak dan dengan demikian terbentuk fokus epilepsi (Lestari dan Mudapati, 2014:Durner et al, 2001).

Hasil penelitian ini sejalan dengan penelitian yang dilakukan oleh Alfatah tahun 2013 terhadap 35 pasien epilepsi yang menunjukan adanya hubungan antara riwayat kejang demam dengan kejadian epilepsi pada anak usia 6 hingga 14 tahun dengan nilai ( $p$ value 0,022). (Alfatah, 2013). Penelitian lain yang dilakukan oleh chairunnisa et al pada tahun 2015 dengan uji analisis fisher's exact didapatkan bahwa terdapat hubungan antara riwayat kejang demam dengan kejadian epilepsi pada anak di BLUD Rumah Sakit Umum Cut Metia Aceh Utara dengan nilai $(p$ value 0,031$)$ dengan $a=$ 0,05 . (Chairunnisa et al, 2018). Hasil yang sejalan juga didapatkan oleh Lestari dan Mudapati (2014) yang mendapatkan kejang demam merupakan faktor risiko terbanyak untuk terjadinya epilepsi pada anak usia $\leq 5$ tahun yaitu sebanyak 21 responden $(67,7 \%)$ dari 31 responden.

\section{SIMPULAN}

Terdapat hubungan riwayat kejang demam dengan kejadian Epilepsi pada anak $\leq 5$ tahun di RSUD Dr. H. Abdul Moeloek Provinsi Lampung Tahun 2018-2019 ( $p$ value 0.032).

\section{SARAN}

Bagi Tempat Penelitian disarankan untuk dapat dijadikan masukan kepada unit pelayanan kesehatan untuk melakukan program penyuluhan kesehatan kepada masyarakat mengenai epilepsi 
pada anak, serta perlu dilakukam penelitian mengenai identifikasi kejang demam lebih spesifik yang berpengaruh terhadap epilepsi pada anak. Bagi lbu disarankan untuk dapat memperhatikan, menambah wawasan tentang kejang demam dan epilepsi, sehingga ibu tidak panik dan mengetahui cara penanggulangannya.Bagi Peneliti Selanjutnya disarankan peneliti selanjutnya dapat melakukan penelitian lanjutan dengan mengkaji dan menganalisis kejang demam (sederhana dan kompleks) dan epilepsi, serta faktor lain yang berhubungan dengan kejang demam dan epilepsy. Peneliti selanjutnya juga dapat mempertimbangkan desain penelitian yang akan digunakkan sehingga dapat bersifat penyempurnaan terhadap penelitian yang telah dilakukan

\section{DAFTAR PUSTAKA}

Alfatah, Ina 2013, 'Hubungan Riwayat Kejang Demam Terhadap Kejadian Epilepsi Pada Anak Usia 6-14 Tahun Di RSUP DR. Kariadi Semarang Periode 2010-2011', Skripsi Mahasiswa Kedokteran Muhammadiyah Semarang.

Andreas, S. T., Saing, J. H., \& Prima, C. (2017). Faktor-faktor yang Mempengaruhi Daya Ingat Anak dengan Epilepsi. Cermin Dunia Kedokteran, 44(12), 855-858.

Andrianti, P. T., Gunawan, P. I., \& Hoesin, F. (2016). Profil Epilepsi Anak dan Keberhasilan Pengobatannya di RSUD Dr. Soetomo Tahun 2013. Sari Pediatri, 18(1), 34-39.

Apsari, R. K. F., Rahardjo, S., AN, E. P., \& UGM, F. Manajemen Anestesi Pada Epilepsi.

Arief, R. F. (2015). Penatalaksanaan Kejang Demam. Continung Medical Education, 42, 658-661.

Beghi, E. (2020). The epidemiology of epilepsy. Neuroepidemiology, 54(2), 185-191.

Chairunnisa, U., Fitriany, J. F. J., \& Sawitri, H. (2018). Hubungan Riwayat Kejang Demam Dengan Kejadian Epilepsi Pada Anak Di Badan Layanan Umum Daerah Rumah Sakit Umum Cut Meutia Aceh Utara Tahun Aceh Utara Tahun 2015. Averrous, 3(2), 39-56.

Durner, M., Keddache, M.A., Tomasini, L., Shinnar. S., Resor, S.R. \& Cohen, J. 2001. Genome scan of idiopathic generalized epilepsy: evidence for major susceptibility gene and modifying genes influencing the seizure type. Ann Neurol, 49(3): 328-35.

Hasibuan, D. K., \& Dimyati, Y. (2020). Kejang Demam sebagai Faktor Predisposisi Epilepsi pada Anak. Cermin

Kedokteran, 47(11), 668-672.

Indrayati, N., \& Haryanti, D. (2019). Gambaran kemampuan orangtua dalam penanganan pertama kejang demam pada anak usia toddler. Jurnal IImiah Permas: Jurnal IImiah STIKES Kendal, 9(2), 149-154.

Ismael, S., Pusponegoro, H. D., Widodo, D. P., Mangunatmadja, I., \& Handryastuti, S. (2016). Rekomendasi Penatalaksanaan Kejang Demam. Unit Kerja Koordinasi Neurologi Ikatan Dokter Anak Indonesia, 116.

Khairani, A. F., Sejahtera, D. P., \& Fauzal, I. A. Strategi pengobatan epilepsi: monoterapi dan politerapi. Berkala NeuroSains, 18(3), 115-119.

Kliegman, R. M., \& St Geme, J. (2019). Nelson textbook of pediatrics part xxvi the nervous system hal 3087,3091,3092, 21st edition. Elsevier.

Laino, D., Mencaroni, E., \& Esposito, S. (2018). Management of Pediatric Febrile Seizures. International journal of environmental research and public health, 15(10), 2232.

Leung, A. K., Hon, K. L., \& Leung, T. N. (2018). Febrile seizures: an overview. Drugs in context, 7.

Mangunatmadja, I (Eds). (2016). Epilepsi pada anak. Jakarta: Badan Penerbit Ikatan Dokter Anak Indonesia.

Marcdante, K. J., \& Kliegman, R. M. (2019). Short stature. Nelson Essentials of Pediatrics section 24 neurology hal 1761. 8th ed. Philadelphia, PA: Elsevier

Maryam, I. S., Wijayanti, I. A. S., \& Tini, K. (2018). Karakteristik Klinis Pasien Epilepsi Di Poliklinik Saraf Rsup Sanglah Periode Januari-Desember 2016. Callosum Neurology Journal, 1(3), 89-94.

Minardi, C., Minacapelli, R., Valastro, P., Vasile, F., Pitino, S., Pavone, P., ... \& Murabito, P. (2019). Epilepsy in children: from diagnosis to treatment with focus on emergency. Journal of clinical medicine, 8(1), 39.

Noradina, N. (2017). Gambaran Pengetahuan Ibu dalam Pencegahan Epilepsi pada Anak Usia 5-12 Tahun di Dusun III Sunggal Kanan Kecamatan Sunggal Kabupaten Deli Serdang. Jurnal IImiah Keperawatan Imelda, 2(1), 40-45.

Notoatmodjo, S. (2012). Metodologi Penelitian Kesehatan. 
Nurhayati, H. K., Susilawati, F., \& Amatiria, G. (2018). Faktor-Faktor yang Berpengaruh dengan Kejadian Kejang Demam pada Pasien Anak di Rumah Sakit Dalam Wilayah Propinsi Lampung. Jurnal Ilmiah Keperawatan Sai Betik, 13(1), 94-102.

Paul, V. K., \& Bagga, A. 2019. Ghai Essential Pediatrics $\left(9^{\text {th }}\right.$ ed). New Delhi: CSB Publication.

Permana, Y. N., Putranti, A. H., \& Setiawan, H. (2020). Faktor-faktor yang Memengaruhi Gambaran Elektroensefalografi Interiktal Anak yang Menderita Epilepsi. Sari Pediatri, 22(1), 13-7.

Pujilestari, S. M., \& Mudapati, A. (2014). FaktorFaktor Yang Terdapat Pada Kejadian Epilepsi Anak Usia 5 Tahun Di Rsud Dr. H. Abdul Moeloek Bandar Lampung Tahun 2010-2014. Jurnal IImu Kedokteran dan Kesehatan, 1(3).

Raharjo, T. B. 2007, Faktor-Faktor Risiko Epilepsi pada Anak Dibawah Usia 6 tahun, Tesis.

Scheffer, I. E., Berkovic, S., Capovilla, G., Connolly, M. B., French, J., Guilhoto, L., ... \& Nordli, D.
R. (2017). ILAE classification of the epilepsies: position paper of the ILAE Commission for Classification and Terminology. Epilepsia, 58(4), 512-521.

Sihaloho, B., \& Indrianti, B. 2019. Gambaran Karakteristik Epilepsi Pada Pasien Anak Di Rumah Sakit Umum Dr. Pirngadi Medan Periode Tahun 2012-2017. Skripsi Mahasiswa Kedokteran Universitas HKBP Nommensen.

Tobing, V. L. 2019. Gambaran Tingkat Pengetahuan Masyarakat Mengenai Epilepsi Di Lingkungan X Kelurahan Tegal Sari Mandala II Medan(Doctoraldissertation).

WHO 2012, World Health Organization, Statistics on Epilepsy, diakses pada 11 November 2020: $\quad h$ htps://www.who.int/en/newsroom/fact-sheets/detail/epilepsy.

Yolanda, N. G. A., Sareharto, T. P., \& Istiadi, H. (2019). Faktor Faktor Yang Berpengaruh Pada Kejadian Epilepsi Intraktabel Anak Di Rsup Dr Kariadi Semarang. Diponegoro Medical Journal (Jurnal Kedokteran Diponegoro), 8(1), 378-38 